\title{
A Comparative Study of Heavy Metals and Trace Elements Concentration in Milk Samples Consumed in Iraq
}

\author{
Nada M. Hasan ${ }^{1 *}$ \\ Jamal K. Al-Saedi ${ }^{1}$ \\ Mustafa K. Jassim ${ }^{2}$
}

Received 20/5/2018, Accepted 6/10/2019, Published 18/3/2020

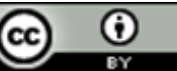

This work is licensed under a Creative Commons Attribution 4.0 International License.

\begin{abstract}
:
The measurements of major and trace elements in different brands of milk powder selected from the Iraqis market via the X-ray fluorescence (XRF) Technique have been studied in the present work. The result of the measurements reveals the high concentrations of sodium, phosphorus, sulfur, chlorine, potassium, calcium and magnesium. Furthermore, low concentrations of aluminum, silicon, iron, bromine, molybdenum, iodine, barium, titanium, manganese, cobalt, chrome, nickel, copper, zinc and lead were detected. Neutron activation analysis (NAA) and Kjeldahl technique were also employed to determine the concentrations of nitrogen. It was found that the nitrogen concentration was in the range of (1.96 - 3.23) \% which is within the permissible limits. The concentrations of the trace elements (copper, manganese, zinc, lead) were verified via the atomic absorption spectrometer (AAS) technique. The results are compared with the authorized limit by the food and agriculture organization and the world health organization (FAO/WHO) standards.
\end{abstract}

Keywords: Concentration elements, Kjeldahl technique, Neutron activation analysis (NAA), X-Ray fluorescence (XRF).

\section{Introduction:}

Milk is a high nutritional food; it is the main source of several vitamins and many minerals that are essential for mammals. It is the most versatile for natural food in terms of configuration and determines the necessary components for a healthy life. The milk and its products are the most important source of calcium $(\mathrm{Ca})$ in our diet. It mostly contains potassium $(\mathrm{K})$, magnesium $(\mathrm{Mg})$ and phosphorus $(\mathrm{P})(1,2)$. Furthermore, it contains more than twenty elements of different trace most of them are necessary and significant, such as copper $(\mathrm{Cu})$, zinc $(\mathrm{Zn})$, manganese $(\mathrm{Mn})$ and iron (Fe) (3). These metals are involved with the enzymes to play an important role in many cell functions (4). It was reported that the lack of these metals cause disturbances and pathological conditions (5).

Furthermore, it was reported that the increasing of heavy elements such as chromium $(\mathrm{Cr})$, cadmium $(\mathrm{Cd})$, lead $(\mathrm{Pb})$ and mercury $(\mathrm{Hg})$ in the milk samples are due to several environmental

${ }^{1}$ Directorate of Nuclear Research and Applications, Ministry of Higher Education, Science and Technology, Baghdad, Iraq

2 Physics Department, College of Education for Pure Science, University of Baghdad, Baghdad, Iraq *Corresponding author: nada66_altai@yahoo.com *ORCID ID: 0000-0002-6160-2836 factors that affect nutrition as well as the manufacturing and the packaging process $(6,7)$. Several damages in the human's organs were noticed due to the absorption of these elements, such as kidney disorder, liver and anemia $(8,9)$. The minor and trace elements in the milk samples are lead $(\mathrm{Pb})$, cadmium $(\mathrm{Cd})$, chromium $(\mathrm{Cr})$, copper $(\mathrm{Cu})$, iron $(\mathrm{Fe})$, manganese $(\mathrm{Mn})$, molybdenum (Mo), nickel (Ni), tin ( $\mathrm{Sn})$, zinc ( $\mathrm{Zn})$ and titanium (Ti). Previous reports indicated the presence of heavy metals in milk samples (10). Metals such as lead, cadmium and mercury were reported in milk samples. This raises a concern, since milk is largely consumed by infants and children (11). On the other hand, the nitrogen $(\mathrm{N})$ contents and the proteins in the milk samples were also studied (11). Protein contains a unique nitrogen ratio and these studies revealed that the amount of nitrogen and milk protein is important in the formation of amino acids responsible for growth and development (12). Different techniques were employed to determine the elements contents in milk samples such as X-ray fluorescence (XRF) (13), Atomic Absorption Spectroscopy (AAS) (14,15), Neutron Activation Analysis (NAA) (16) and Plasma Atomic Emission Spectrometry (17). The important elements and their concentrations needed by the children body as 
recommended by the World Health Organization (WHO) are shown in Table 1 (18). The aim of this study is to determine the concentration of elements in selected milks powder that are consumed widely in Iraq. The samples were prepared and analyzed through the X-rays fluorescence, neutron activation analysis, atomic absorption spectrometer and Kjeldahl technology are employed. The results are compared with the international organizations regulations.

Table 1. The elements necessary by the Infants and children with recommended amounts by the WHO.

\begin{tabular}{|c|c|c|c|c|}
\hline Elements & $\begin{array}{c}\text { Infants Age (year) } \\
0.0-0.5\end{array}$ & $\begin{array}{c}\text { Infants Age (year) } \\
0.5-1\end{array}$ & $\begin{array}{l}\text { Children Age } \\
\text { (year) 1-3 }\end{array}$ & $\begin{array}{l}\text { Children Age } \\
\text { (year) 4-8 }\end{array}$ \\
\hline Calcium (mg) & 200 & 260 & 700 & 1000 \\
\hline Magnesium(mg) & 30 & 75 & 80 & 130 \\
\hline Phosphorus(mg) & 100 & 275 & 468 & 500 \\
\hline Potassium (g) & 0.4 & 0.7 & 3.0 & 3.8 \\
\hline Sodium (g) & 0.12 & 0.37 & 1.0 & 1.2 \\
\hline Chloride(g) & 0.18 & 0.57 & 1.5 & 1.9 \\
\hline Manganese(mg) & 0.003 & 0.6 & 1.2 & 1.5 \\
\hline Selenium $(\mu \mathrm{g})$ & 15 & 20 & 20 & 50 \\
\hline Molybdenum $(\mu \mathrm{g})$ & 2 & 3 & 17 & 22 \\
\hline Chromium ( $\mu \mathrm{g})$ & 0.2 & 5.5 & 11 & 15 \\
\hline
\end{tabular}

\section{Materials and Method:}

\section{Sample Collection and Preparation}

Eight samples were selected referring to the most consumed ones by the Iraqi population. The samples collected from the Iraqi markets are Anchor, Nan, Similac, Nido, Gold, Guigoz /1, Guigoz / 2 and Novalac. Initially, the samples were dried for $24 \mathrm{hr}$ in a drying oven. An equal mass of four grams of each samples was pressed via hydraulic piston with pressure of $15 \mathrm{Ton} / \mathrm{cm}^{2}$. The result tablets were in a diameter of $32 \mathrm{~mm}$ and were kept in a vacuum dissector for later measurements.

\section{The Instrumentations}

\section{The X-Ray Florescence (XRF)}

In this work, XRF spectrometry (Spectro Xepos, SPECTRO Analytical Instruments) unit was employed to measure the main and the trace elements of the milk samples. The unit utilized a silicone drift lithium detector, with an energy resolution $45 \mathrm{eV}$ at photon energy $5.9 \mathrm{keV}$ of iron (Fe-55) isotope. The detector was cooled using Peltier effect and the thickness of beryllium window was approximately $0.076 \mathrm{~mm}$. Several targets were used to generate different $\mathrm{X}$ - ray energies. The targets are the highly oriented pyrolytic graphite (HOPG), alumina $\left(\mathrm{Al}_{2} \mathrm{O}_{3}\right)$ and Molybdenum. Precision and accuracy of the results were tested by normal standard reference analysis in XRF unit. The results imply that the unit is credible for such measurements. Table 2 proves the ability of X-ray fluorescence technique to analyze a diverse collection of samples with good precision.

Table 2. shows the comparison of results between experimental data and the results published in certificate data to [PCC-1]

\begin{tabular}{llllllllllll}
\hline No & A. $\mathbf{~}$ & E.S & Con* & Con** & Error\% & No. & A. N. & E.S. & Con.* & Con.** & Error\% \\
\hline $\mathbf{1}$ & 11 & $\mathrm{Na}$ & 0.34 & 0.36 & 5.55 & 10 & 25 & $\mathrm{Mn}$ & 0.517 & 0.5 & 3.4 \\
$\mathbf{2}$ & 12 & $\mathrm{Mg}$ & 28.80 & 26.19 & 9.96 & 11 & 26 & $\mathrm{Fe}$ & 1.804 & 1.25 & 44.32 \\
$\mathbf{3}$ & 13 & $\mathrm{Al}$ & 0.32 & 0.35 & 8.57 & 12 & 27 & $\mathrm{Co}$ & 0.0066 & 0.0062 & 6.4 \\
$\mathbf{4}$ & 14 & $\mathrm{Si}$ & 20.69 & 19.48 & 6.21 & 13 & 28 & $\mathrm{Ni}$ & 0.349 & 0.372 & 5.94 \\
$\mathbf{5}$ & 15 & $\mathrm{p}$ & 0.38 & 0.40 & 5.00 & 14 & 29 & $\mathrm{Cu}$ & 0.0001 & 0.0001 & 0.0 \\
$\mathbf{5}$ & 16 & $\mathrm{~S}$ & 0.145 & 0.244 & 26.64 & 15 & 30 & $\mathrm{Zn}$ & 1.64 & 1.87 & 12.42 \\
$\mathbf{6}$ & 17 & $\mathrm{Cl}$ & 0.761 & 0.875 & 13.03 & 16 & 34 & $\mathrm{Se}$ & 0.002 & 0.0031 & 35.48 \\
$\mathbf{7}$ & 19 & $\mathrm{~K}$ & 8.012 & 10.00 & 19.88 & 17 & 42 & $\mathrm{Mo}$ & 0.004 & 0.0031 & 29 \\
$\mathbf{8}$ & 20 & $\mathrm{Ca}$ & 0.22 & 0.272 & 26.47 & 18 & 80 & $\mathrm{Hg}$ & 0.0013 & 0.0013 & 0.0 \\
$\mathbf{9}$ & 24 & $\mathrm{Cr}$ & 0.021 & 0.031 & 32.25 & 19 & 82 & $\mathrm{~Pb}$ & 0.0001 & 0.0001 & 0.0 \\
\hline
\end{tabular}

A.N.: atomic number, E.S.: element symbol, Con*: The experimental concentration (\%), Con**: The certificate concentration (\%).

Neutron Activation Analyses (NAA)

Neutron activation analysis was employed to determine the concentration of nitrogen. The samples were irradiated with the standard samples by a neutron source with a flux of $4 \times 10^{4} \mathrm{n} / \mathrm{cm}^{2}$.s at irradiation time $1 \mathrm{~min}$. The result of the gamma emitted from the (n, gamma) reaction was measured via a gamma spectroscopy unit. The system consisted of a $\mathrm{NaI}(\mathrm{TI})$ detector with energy resolution (FWHM) at ${ }^{137} \mathrm{CS}$ is $8.5 \%$ connected to a 
personal computer via Integrated Computer Spectrometer (ICS-PCI-4k) card. The resulted spectrums were analyzed via the gamma spectroscopy software.

\section{Atomic Absorption Spectrometry (AAS)}

The atomic absorption spectrometry (AAS) technique is widely employed to determine the quantitative and qualitative elements in a sample (19). This technique is considered the best to measure the concentrations of trace elements with the detection limit less than part per billion (ppb) (20). For samples to be analyzed using this technique, several chemical processes need to be done before using the AAS unit. Initially, the milk samples were digested using acids nitric, sulfuric and perchlorate at $80^{\circ} \mathrm{C}$. The samples then were gradually brought to the boiling temperature for four hours, cooled, filtered and diluted to $100 \mathrm{ml}$ volume with deionized water.

\section{Kjeldahl method}

The Kjeldahl method is recognized widely in the detection of the nitrogen and then calculating the protein. This method consists of several basic steps. The sample is inserted in a test tube and digested with the (anhydrous potassium sulfate $\left(\mathrm{K}_{2} \mathrm{SO}_{4}\right)$, Selenium (Se), concentrated sulphuric acid $\left(\mathrm{H}_{2} \mathrm{SO}_{4}\right)$ and hydrogen peroxide $\left.\left(\mathrm{H}_{2} \mathrm{O}_{2}\right)\right)$. The sample is digested using the following reactions (21).

$\mathrm{N}+\mathrm{H}_{2} \mathrm{SO}_{4} \rightarrow \mathrm{CO}_{2}+\mathrm{H}_{2} \mathrm{O}+\left(\mathrm{NH}_{4}\right)_{2} \mathrm{SO}_{4} \quad \ldots 1$

the ammonia is release according to;

$\left(\mathrm{NH}_{4}\right)_{2} \mathrm{SO}_{4}+2 \mathrm{NaOH} \rightarrow 2 \mathrm{NH}_{3}+\mathrm{Na}_{2} \mathrm{SO}_{4}+2 \mathrm{H}_{2} \mathrm{O} \ldots 2$ the ammonia reacts with sulfuric acid;

$2 \mathrm{NH}_{3}+\mathrm{H}_{2} \mathrm{SO}_{4} \rightarrow\left(\mathrm{NH}_{4}\right)_{2} \mathrm{SO}_{4} \ldots 3$

The prepared tube had heated at $420{ }^{\circ} \mathrm{C}$ for $30 \mathrm{~min}$ and then cooled to $50-60{ }^{\circ} \mathrm{C}$. The distillation of the ammonia into trapping solution and the

quantification of the ammonic by titration with a standard solution concentration (22). The Kjeldahl method dose not measure the concentration of protein directly. The protein concentrations are estimated by multiplying the measured nitrogen concentration with the conversion factor $(F)$ that equals to 6.3 (21).

\section{Results and Discussions: \\ Concentration elements using XRF and AAS}

The results of the milk samples consumed widely by the Iraqi population was measured through the XRF and were verified through AAS. The results can be classified to major elements which are $\mathrm{Na}, \mathrm{P}, \mathrm{S}, \mathrm{Cl}, \mathrm{K}, \mathrm{Ca}$ and $\mathrm{Mg}$, covering the vast range of elements. Beside the major elements, trace elements were found in the selected milk samples. These are $\mathrm{Al}, \mathrm{Si}, \mathrm{Fe}, \mathrm{Zn}, \mathrm{Br}, \mathrm{Rb}, \mathrm{Mo}$, I, $\mathrm{Ba}, \mathrm{Ti}, \mathrm{Mn}, \mathrm{Co}, \mathrm{Cu}, \mathrm{Mn}, \mathrm{Pb}$.

Major Elements

Fig 1 shows the results of the major elements in the milk samples, the results reveal that there is a small variation in the measured concentrations of the major elements $\mathrm{Na}, \mathrm{S}, \mathrm{Ca}, \mathrm{K}$, $\mathrm{Mg}$, and $\mathrm{P}$ for most samples which distinguish the quality of the milk (23). It was found that the Nido contains the highest concentration of essential elements. The average range concentrations are as follows: $\mathrm{Ca}(0.750$ - 1.766) \%, K (1.00-1.87) \%, Mg (0.047- 0.138$) \%, \mathrm{Na}(0.206-0.417) \%, \mathrm{~S}(0.23-$ $0.527) \%$ and $\mathrm{P}(0.62-1.23) \%$. In the measured samples containing $\mathrm{Ca}, \mathrm{P}, \mathrm{Mg}, \mathrm{Na}, \mathrm{Al}$, and $\mathrm{K}$, the concentrations of these elements are within the permissible limits of World Health Organization (WHO) (24) as shown in Table 3.

Table 3. Identify concentrations of certain elements and compare them to limits allowed by WHO

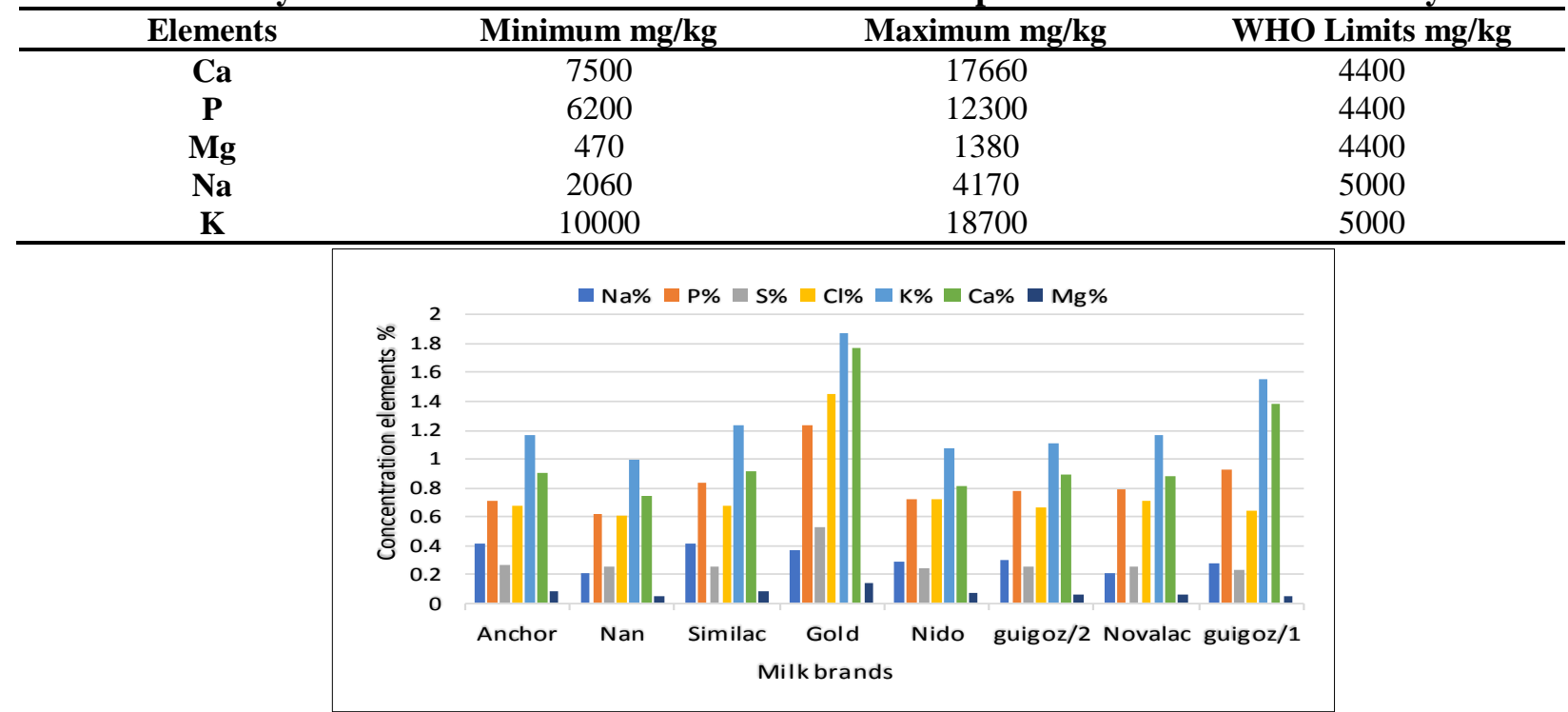

Figure 1. Major Concentration Elements (\%) using XRF technique 


\section{Trace Elements}

The large differences in the group of trace elements $\mathrm{Al}, \mathrm{Si}, \mathrm{Fe}, \mathrm{Br}, \mathrm{Mo}, \mathrm{I}, \mathrm{Ba}$ and $\mathrm{Ti}, \mathrm{Mn}, \mathrm{Co}$, $\mathrm{Cr}$, Ni were revealed in Fig 2 and 3 respectively. Fig 4 also shows a different concentration of $\mathrm{Zn}$ for all samples. The different concentrations of these elements depend on the diet of cows (25). The results showed the inverse correlation among $\mathrm{Fe}, \mathrm{Si}$ and $\mathrm{Zn}$ in most of the measured samples. The differences in the concentration of $\mathrm{Al}, \mathrm{Zn}, \mathrm{Mo}$, I was insignificant for most of the measured samples. Furthermore, it was found that there is a direct relationship correlated between $\mathrm{Cu}, \mathrm{Fe}$ and inverse correlation with $\mathrm{Mn}$. Copper deficiency is very dangerous due to the relationship between the copper and iron and associated diseases with iron deficiency. Copper is essentially stimulating the ferroxidase enzymes responsible for the movement of iron in tissues, therefore insufficient copper will probably cause iron deficiency, consequently, this will probably cause diseases that are related to the lack of these two elements. An increase in the proportion of manganese weakens the activity of copper and therefore affects the proportions of iron. It is usually the prevention of mineral deficiency in milk by using cows diet rich in minerals by licking minerals (26). It was reported that several external factors such as environmental pollution, packaging and storage probably might increase the concentration of lead and cadmium (27), the mean value of lead and cadmium is leas then the limit of World Health Organization (WHO) $(1 \mathrm{mg} / \mathrm{kg}, 0.03$ $\mathrm{mg} / \mathrm{kg}$ ) (28). In the measured samples also containing $\mathrm{Cr}, \mathrm{Cu}, \mathrm{Fe}, \mathrm{Mn}, \mathrm{Ni}$, and $\mathrm{Zn}$, the concentrations of these elements are within the permissible limits of World Health Organization (WHO) (29). as shown in Table4.

Table 4. Identify concentrations of certain elements and compare them to limits allowed by WHO

\begin{tabular}{cccc}
\hline Elements & Minimum $\mathbf{~ m g} / \mathbf{k g}$ & Maximum $\mathbf{~ g /} / \mathbf{k g}$ & WHO Limits $\mathbf{~ m g} / \mathbf{k g}$ \\
\hline $\mathbf{C r}$ & 3.8 & 8.7 & 1.61 \\
$\mathbf{C u}$ & 1.5 & 3.4 & 24.2 \\
$\mathbf{F e}$ & 10 & 490 & 0.5 \\
$\mathbf{M n}$ & 0.1 & 6.4 & 55.5 \\
$\mathbf{N i}$ & 0.5 & 1.5 & 0.43 \\
$\mathbf{Z n}$ & 20 & 100 & 121 \\
\hline
\end{tabular}

The concentrations of $\mathrm{Al}, \mathrm{Si}, \mathrm{Fe}, \mathrm{Zn}, \mathrm{Br}$, $\mathrm{Rb}$, Mo, I, Ba, Ti, Mn, Co, Cu, Mn, Cr, Ni and $\mathrm{Pb}$ for milk samples were measured and their range were $(46$ - 99) ppm, (20-930) ppm, (10-490) ppm, (20-60) ppm, (10-50) ppm, (10-470) ppm, (10-20) ppm, (20-70) ppm, (19-120) ppm, (0.7-6.7) ppm, (0.1-9.9) ppm, (1.0-2.1) ppm, (1.5-3.4) ppm, (0.19.9) ppm (3.8 -8.7) ppm, (0.5-1.5) ppm and (0.51.3)ppm, respectively.

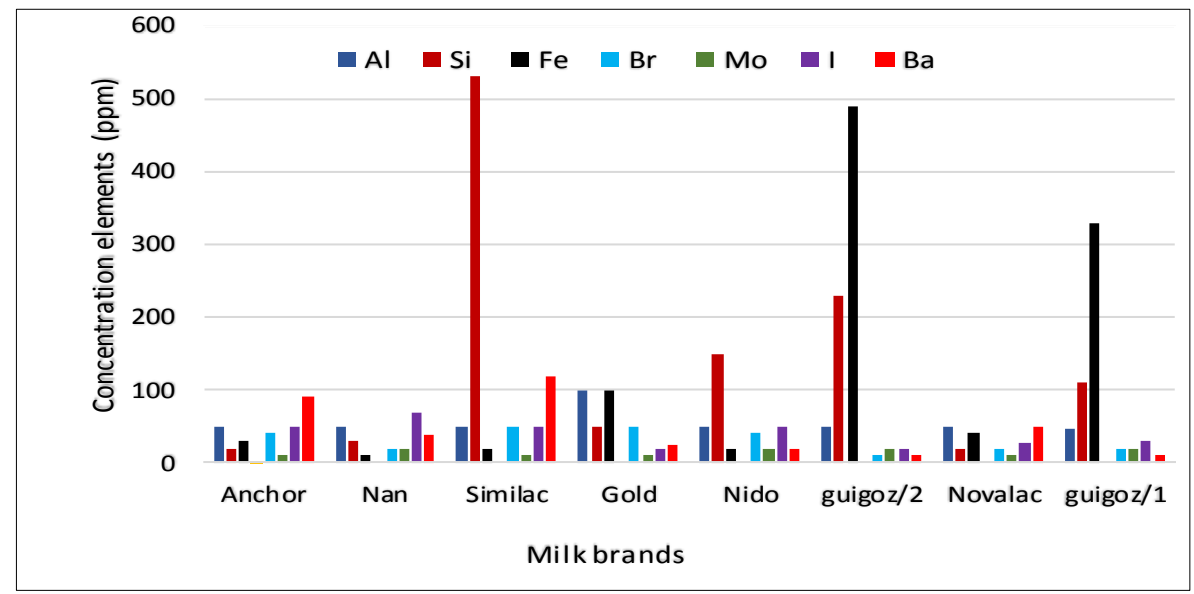

Figure 2. Trace concentration elements (ppm) using XRF technique 


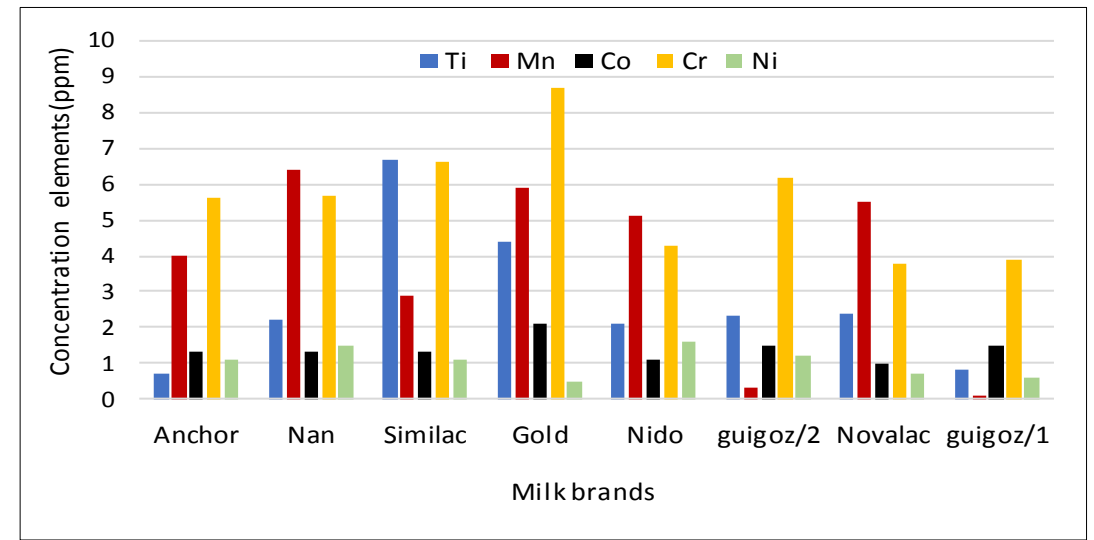

\section{Figure 3. Trace concentration elements $\mathrm{Ti}, \mathrm{Mn}, \mathrm{Co}, \mathrm{Cr}$ and $\mathrm{Ni}(\mathrm{ppm})$ using $\mathrm{XRF}$ technique}

The results of selective elements were verified via the AAS. Fig 4 and 5 reveal the elements $\mathrm{Cu}, \mathrm{Mn}, \mathrm{Pb}, \mathrm{Zn}$ concentration in the eight samples of the milk. The concentrations of elements were (0.61-3.5) ppm, (1.5-7.8) ppm, (10.01-50.2) ppm, (0.53-1.3) ppm, respectively. Compared with the results obtained from the XRF technique, Milk is a poor source of $\mathrm{Cu}(30)$. In all the samples measured, lead contents less than authorized limit by $\mathrm{FAO} / \mathrm{WHO}$ standard $(\mathrm{Pb}: 20 \mathrm{mg} / \mathrm{kg})(31)$. The concentration of lead is based on feeding the cows method of packaging and storage (27).

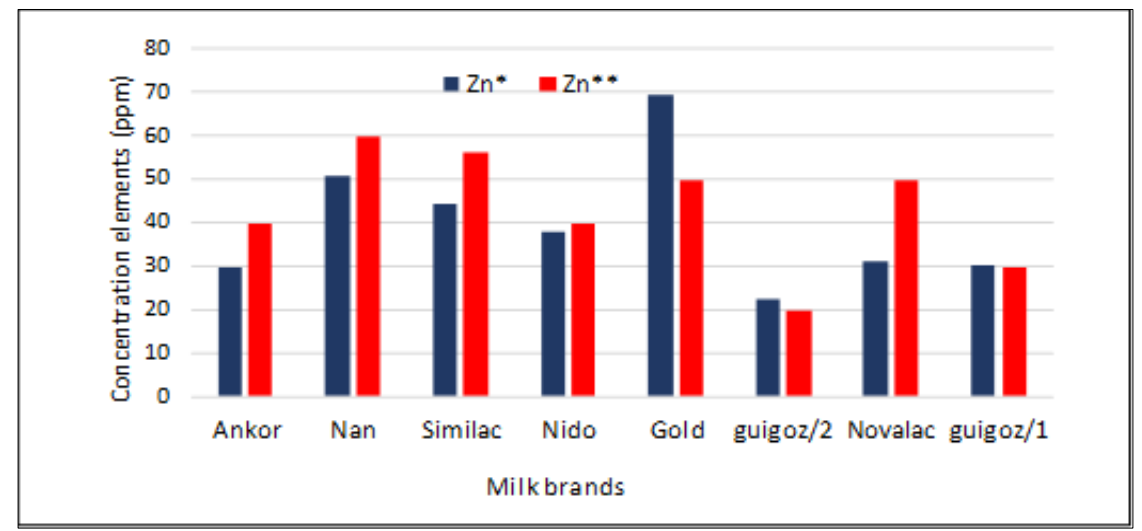

Figure 4. Concentration of Zinc using AAS*technique and XRF** technique

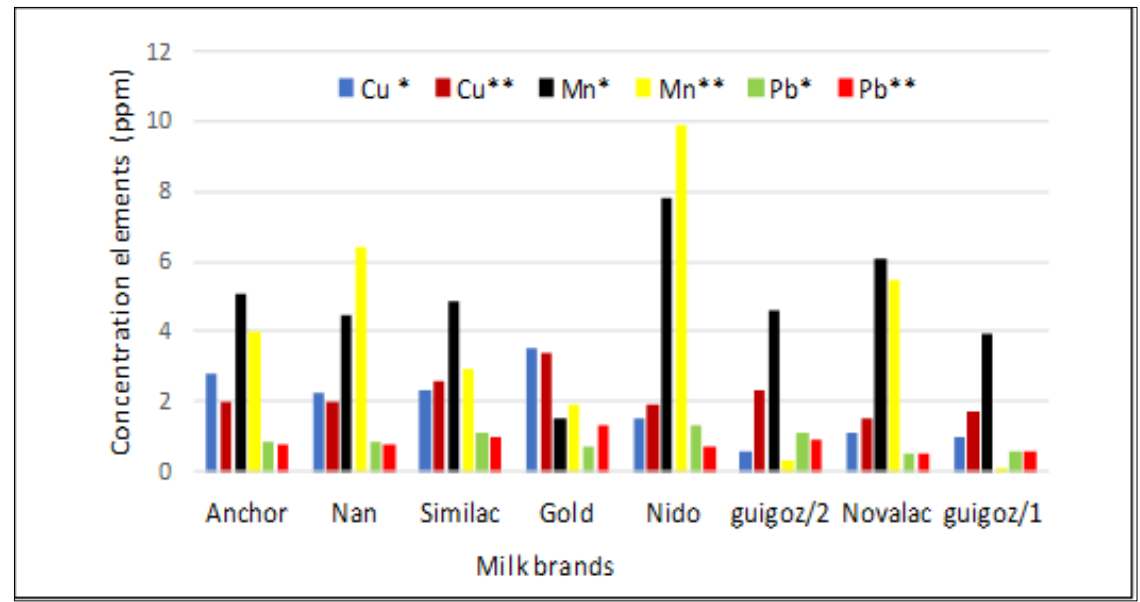

Figure 5. Concentration elements (ppm) using AAS*technique and compare with $\mathrm{XRF}^{* *}$

\section{Concentration of nitrogen and protein}

From Fig 6 it can be noticed that the highest concentration of protein is $22.41 \%$ in Nido and less concentration is $12.82 \%$ in Similac. The value of protein is 6.38 multiplied by the total nitrogen determined by the kjeldahl method. Diet affects the proportions of milk protein and is an effective tool for evaluating nutrition programs. Increasing the proportion of protein has severe consequences (32). Calculating the protein in this way represents the 
raw protein because the measured nitrogen is derived from protein and from non-protein sources. When using melamine, a type of plastic, rich in nitrogen, illegally added with animal feed to increase the proportion of nitrogen causes a significant risk to human health, for example causes renal failure and kidney stones (33).

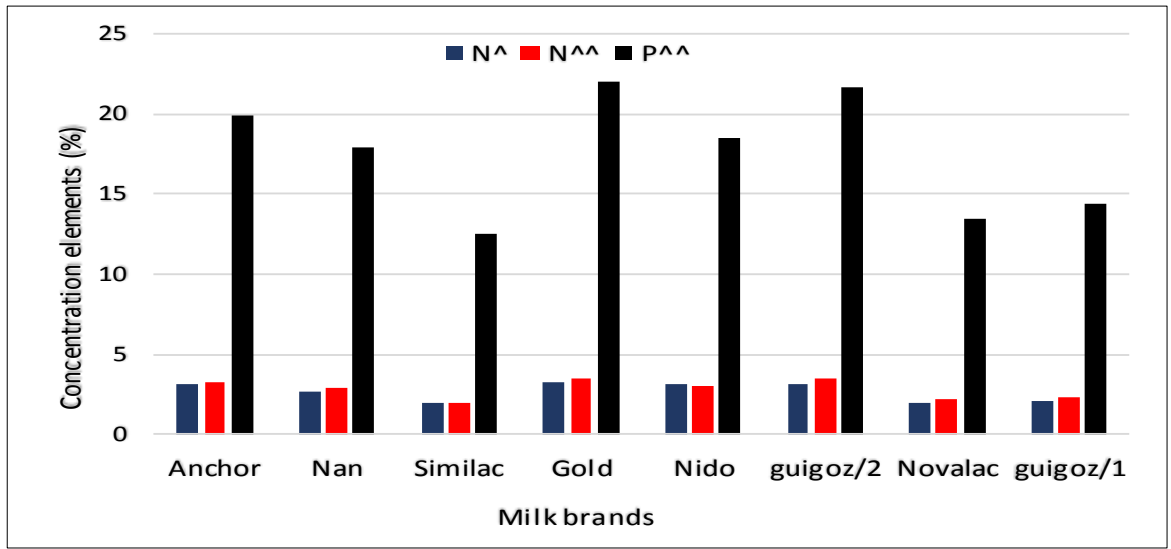

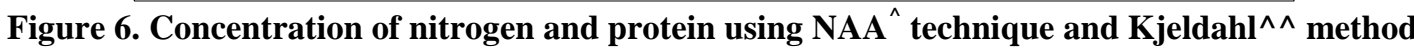

The World Health Organization (WHO) does not approve the addition of melamine to animal feed. The methods used to calculate the level of protein fail to distinguish between the nitrogen output from the melamine or amino acids, making the level of protein not real (34). The World Health Organization (WHO) has identified the protein level $34 \%$ in the solid milk segment depending on the country producing the milk, how it is treated, and the withdrawal or addition of components to milk (24).

\section{Conclusions:}

In summary, XRF, NAA, AAS were used to analyze the minerals in several milk powder samples. The samples were collected from the Iraqi markets which are used frequently by the local populations. The result of the measurements reveals two main groups of samples, one with high concentrations namely $\mathrm{Na}, \mathrm{P}, \mathrm{S}, \mathrm{Cl}, \mathrm{K}, \mathrm{Ca}$ and $\mathrm{Mg}$. The second group with low concentrations namely, Al, Si, Fe, Br, Mo, I, Ba, Ti, Mn and Co. Furthermore, selected elements concentrations were verified via XRF and AAS methods.

The results of this study show that the milk content has an effect on the nutritional quality of milk, where the level of heavy elements is less than the permissible limits by FAO/WHO as well as determining protein level in milk and its effect on milk quality. It is necessary to make further studies to evaluate the contents of the major and trace elements and ensure the absence of potential toxic risks.

\section{Acknowledgments}

The authors acknowledge the support of the Iraqi Ministry of Science and Technology for completing this study.

\section{Conflicts of Interest: None.}

\section{Reference:}

1. Naeem K, Inseon J, Inmin H, Jaesung K, Sung H Ch, Eunyeong $\mathrm{N}$, et al. Analysis of minor and trace elements in milk and yogurts by inductively coupled plasma-mass spectrometry (ICP- MS). J Food Chem. 2014; 147: 220-224.

2. Sumya K, Masum AKM, Islam MA, Harun RMd. Mineral profiles of powdered milk, yoghurt, ice cream and raw milk, Asian J Med Biol Res. 2017 ;3 (2): 294-297

3. Simun Z, Neven A, Jasmina H, Dubravka S. Mineral elements in milk and dairy products, J Mljekarstvo. 2011; 62 (2), 111-125.

4. Ahlam AE, Amer AA, Abo El- Makarem HS, Hend HAH. Heavy Metals Residues in Some Dairy Products. AJVS. 2017 ;52(1): 334-346.

5. Khalil HM , Seliem AF. Determination of heavy metals $(\mathrm{Pb}, \mathrm{Cd})$ and some trace elements in milk and milk products collected from Najran region in K.S.A. JUC. 2013; 9(1): 113-120.

6. Abdulkhaliq A, Swaileh KM, Hussein RM , Matani M. Levels of metals $(\mathrm{Cd}, \mathrm{Pb}, \mathrm{Cu}$ and $\mathrm{Fe})$ in cow's milk, dairy products and hens' eggs from the West Bank, Palestine. IFRJ. 2013 ;19 (3): 1089-1094.

7. Nina B, Marija S, Maja D, Bozica SK, Ivana V, Durdica B, et al. Concentrations of microelements $\mathrm{Al}, \mathrm{Co}, \mathrm{Cr}, \mathrm{Li}, \mathrm{Mo}, \mathrm{Ni}, \mathrm{Sb}$ and $\mathrm{Sr}$ in the milk of Croatian Cold blood mares, J Mljekarstvo. 2013; 63(3), 150-157.

8. Arafa MSM, Walaa AM. Heavy metals and trace elements levels in milk and milk products, J Food Meas Charact. 2014 ;8:381-388. 
9. Tunegova M, Toman R, Tancin V. heavy Metals Environmental Contamintal and Their Occurrence in Different Types of Milk (Slovak) J Anim Sci. 49, 2016; (3): 122-131.

10. Parisa ZF, aezeh Sh, Mahdieh M , Tamaskani MZ. An Overview of the Heavy Metal Contamination in Milk and Dairy Products. ASPS. 2018; 2(7):8-21.

11. Licata P, Trombetta D, Cristani M, Giofre F, Martino $\mathrm{D}$, Calo M, et al. Levels of toxic and essential metals in samples of bovine milk from various dairy farms in Calabria (Italy). J Environ Int. 2004 ;30: 1-6.

12. Sinisa M, Kresimir S, Samir K. Variation in nitrogen components of sheep milk in sub-Mediterranean area, J. Mljekarstvo, 2014 ;64 (1): 27-33.

13. Omer S, Tugba B, Hasan B, Gokhan A. Determination of Trace Elements in Ashes of Milk Samples by Using XRF Technique. Asian J Chem. 2013; 25(8): 4385-4388.

14. Ijaz A, Aqal Z, Noreen S, Muhammad MA, Shah R, Atif A, et al. Atomic Absorption Spectrophotometry Detection of Heavy Metals in Milk of Camel, Cattle, Buffalo and Goat from Various Areas of KhyberPakhtunkhwa (KPK) (Pakistan). J Anal Bioanal Tech. 2017 ;8(3):1-6.

15. Lawal NS , Tajuddeen Nand Garba BB. Assessment of some mineral elements indifferent brands of powdered milk sold in Samaru Zaria (Nigeria). IFRJ. 2015;22(6): 2634-2636.

16. Carmen SK,Vera AM. Determination of major and minor elements indairy products through inductively coupled plasma optical emission spectrometry after wet partial digestion and neutron activation analysis $\mathrm{j}$ food chem. 2007;100:390-395.

17. Sirelkhatim BE, El-naggar AY. Determination of Micro minerals in Milk from Farm and Pasture-reared Cow, Goat and Camel; using Inductively Coupled Plasma-Optical Emission Spectrometry. Orient J Chem. 2016 ;32(1): 341-347

18. Zamberlin S, Antunac N, Havranek J, Samarzija D. Mineral elements in milk and dairy products $\mathrm{J}$. Mljekarstvo, 2012;62:111-125.

19. Antunovic Z, Bogut I, Sencic D, Katic M, Mijic P. Concentrations of selected toxic elements (cadmium, lead, mercury and arsenic) in ewe milk in dependence on lactation stage. J Anim Sci. 2005;50, (8): 369375.

20. Farid SM, Enani MA, Wajid SA. Determination of Trace Elements in Cow's Milk in Saudi Arabia, JKAU: Eng Sci. 2004;15(2):131-140.

21. Maehre HK, Dalheim L, Edvinsen GK., Elvevoll EO, Jensen, I J. Protein Determination-Method Matters. J.Foods ,2018;7:5-16 .
22. Neide KK, Mauricio MG, Cassia TBVZ, Dimas AMZ. Determination of total proteins in cow milk powder samples: a comparative study between the Kjeldahl method and spectrophotometric methods. J Food Compos Anal. 2003;16:507-516.

23. Massimo DM, Correlatori D, Mauro PD, Giovanni N. Characterization of major mineral contents in milk of four cattle breeds, University Deglistudi Padova. 2014-2015

24. World health Organization, food and agriculture organization of the united nation (WHO/FAO) Milk and Milk Products, Fermenten Milks (Codex Stan 243-2003) 2011:6-16

25. Dobrzanski Z, Koacz R, Gorecka H, Chojnacka K, Bartkowiak A. The Content of Microelements and Trace Elements in Raw Milk from Cows in the Silesian Region. Pol J Environ Stud. 2005;14, (5): 685-689.

26. Natalia P, Joanna P, Witold SP, Anna FR, Andrzej D, Kamil S, et al. Concentrations of microelements and trace elements in milk of Jersey cows. Indian J Anim Res. 2016;3 (3): 268-275.

27. Abolfazl AD, Ali E, Abolfaz AG, Kambiz N, Asghar AY, Soheil $\mathrm{H}$, et al. Evaluation and determination of toxic metals (Lead and Cadmium) in cow milk collected from East Azerbaijan (Iran) Euro J Exp Bio. 2012;2 (1):261-265.

28. Enb A, Abou Donia MA, Abd-Rabou NS, Abou-Arab AAK , El-Senaity MH. Chemical Composition of Raw Milk and Heavy Metals Behavior During Processing of Milk Products . G.V. 2009;3 (3): 268275.

29. Ijaz A, Aqal Z, Noreen S, Muhammad MA, Shah R, Atif A, et al. Atomic Absorption Spectrophotometer Detection of Heavy Metals in Milk of Camel, Cattle, Buffalo and Goat from Various Areas of KhyberPakhtunkhwa (KPK)( Pakistan). J Anal Bioanal Tech. 2017;8(3):1-6.

30. Renata P, Jerzy W, Piotr S, Bogumiła P, Agnieszka TM. Concentrations of toxic heavy metals and trace elements in raw milk of Simmental and HolsteinFriesian cows from organic farm, Environ Monit Assess. 2013;185(10):8383-8392.

31.FAO/WHO, Technical Report Series 837, World health Organization: Geneva, Switzerland, (1993).

32. Emery RS. Feeding for increased milk protein. J Dairy Sci. 1978;81:825.

33. FAO/WHO World Health Organization, Emergencies preparedness, response, Questions and Answers on melamine. 2017.

34. Stephen C. Melamine - an industry staple. South China Morning Post. Hong Kong, 2008. 
دراسة مقارنة للمعادن الثقيلة وتركيز العناصر النادرة في عينات الحليب المستهلكة في العراق

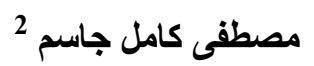

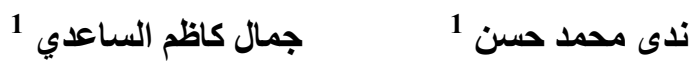

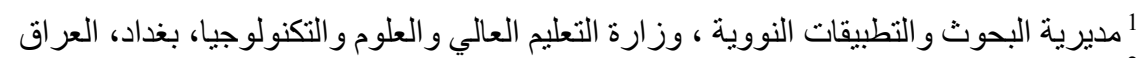
2 قسم القيزياء،كلية التربية للعلوم الصرفة ، جامعة بغداد التعاد ، بغداد، العراق

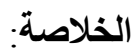

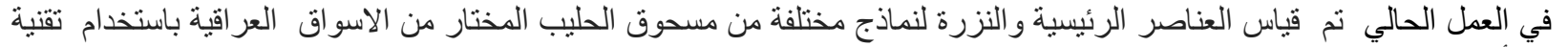

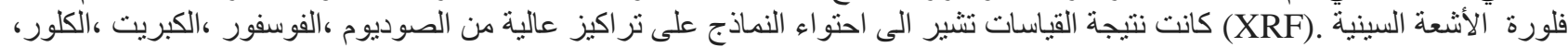

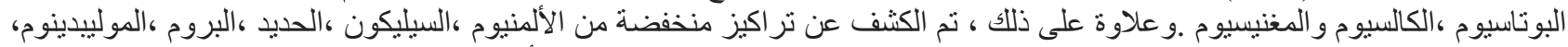

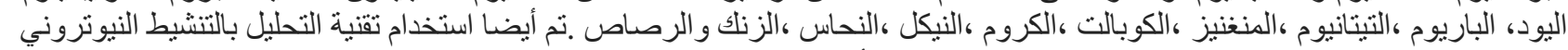

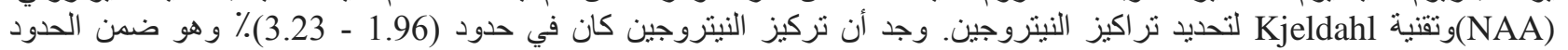

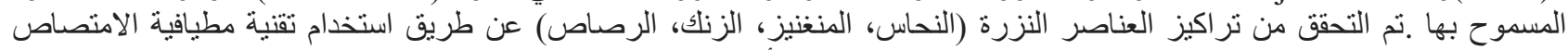

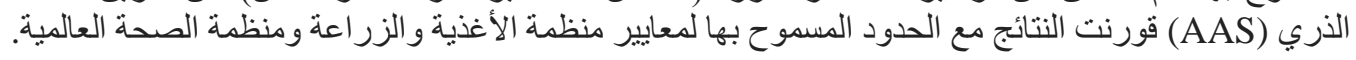

الكلمات المفتاحية: نر اكيز العناصر ، تقنية كيلدال، تحليل التتشيط النيوتروني (NAA) ، فلورة الأشعة السينية (XRF) 